\title{
A Meta-Analysis on the Risk Factors of Low Back Pain in Health Workers
}

\author{
Muh. Syaiful Akbar'1), Setyo Sri Rahardjo²), Dono Indarto²) \\ 1)Masters Program in Public Health, Universitas Sebelas Maret \\ 2)Faculty of Medicine, Universitas Sebelas Maret
}

\section{ABSTRACT}

Background: Low back pain is a common problem in global health. Low back pain is very commonly found with disabilities compared to other conditions. Complaints of the musculoskeletal system are complaints in parts of the skeletal muscles that a person feels from very mild to very painful. There is a possible factor that can cause the occurrence of lower back pain in health workers such as length of work in a day. This study aimed to analyze the length of work in a day for health workers.

Subjects and Method: This was a meta-analysis and systematic study using electronic databases of Pubmed, Science Direct, Scopus, Google Scholar, and Springer Link. The keywords for searching articles were as follows: risk factor, low back pain, medical person, health workers, Cross Sectional. The articles studied were full-text articles with cross-sectional study design. The articles were collected using PRISMA diagrams and analyzed using the ReviewManager 5.4.
Results: Length of work by $\geq 5$ years $(\mathrm{aOR}=1.58$; $95 \% \mathrm{CI}=1.27$ to $1.96 ; \mathrm{p}<0.0001$ ) was a factor that could increase the incidence of low back pain in health workers. The result was statistically significant. Tenure of work by $\geq 6$ hours in a day $(\mathrm{aOR}=1.53 ; 95 \% \mathrm{CI}=0.71$ to $3.29 ; \mathrm{p}=0.28)$ was a factor that could increase the incidence of lower back pain in health workers. However, the result was statistically non-significant.

Conclusion: Longer length of work/day increase the risk of lower back pain in health workers.

Keywords: tenure, low back pain, health workers

\section{Correspondence:}

Muh. Syaiful Akbar. Masters Program in Public Health, Universitas Sebelas Maret. Jl. Ir. Sutami 36A, Surakarta 57126, Central Java. Email: asyaifulop@gmail.com. Mobile: 082325070569.

Cite this as:

Akbar MS, Rahardjo SS, Indarto D (2020). A Meta-Analysis on the Risk Factors of Low Back Pain in Health Workers. J Epidemiol Public Health. 05(02): 237-244. https://doi.org/10.26911/jepublichealth.2020.05.02.11 (c) (i) (2) Journal of Epidemiology and Public Health is licensed under a Creative Commons Attribution-Non Commercial-Share Alike 4.o International License.

\section{BACKGROUND}

Lower back pain can interfere with an individual's activities in doing work. Therefore, it is a special concern because it is related to health complaints at work. $37 \%$ of western industrial society complained about lower back pain related to the activities carried out (Farnam et al, 2016).

The Belgian health interview survey stated that $21 \%$ of people in Belgium who were $>15$ years of age had low back pain. $62.1 \%$ of workers in Turkey had low back pain after working in the same body position continuously (Farnamet al., 2016).

In Indonesia, the prevalence of low back pain according to the data from the Directorate General of Health Services of the Ministry of Health of the Republic of Indonesia in 2018 was $18 \%$. The prevalence can increase along with the increasing age. It also often occurs in the middle and early decades of age.

The type of work that is at risk of causing complaints of low back pain is the health worker who cares for patients. They are more 
susceptible to low back pain due to the behavior caused at work. There are many factors can cause low back pain such as excessive activity while working, wrong position/posture, and the physical nature of work. However, generally, the factors causing low back pain in a worker are sex, age, BMI, years of service, and length of work, posture, and standing position (Chaman., 2015). The prevalence of low back pain among health workers in the anesthesiology work area of Dr. Hasan sadikin Hospital in Bandung was 37.7\% (Patrianingrum et al, 2015).

Based on another study conducted by Ibrahim et al. (2019) at the Malaysian General Hospital, $76.5 \%$ of health workers had low back pain with risk factors such as body position while working, fatigue, manual handling, and length of work of more than seven hours a day. Based on a study conducted in Turkey (2014), 48.3\% of workers had mild pain, $24.8 \%$ of workers had moderate pain and $10.3 \%$ of workers had severe pain. $62.1 \%$ of these workers had lower back pain after working with the same body position continuously (Farnamet al., 2016).

The activities carried out cause spasms of the muscles in the back so that pain in the lower back occurs. This condition is in the form of an unpleasant condition experienced by a person from sensory experiences such as pain felt in the lower back area which could occur due to physical factors, work, and psychosocial factors (Ditjen Yankes, 2018).

\section{SUBJECTS AND METHOD}

\section{Study Design}

This study used systematic review, namely meta-analysis. This study was carried out by selecting the articles in several databases, namely Pubmed, Science Direct, Scopus,
Google Scholar, and Springer Link. The keywords to search for the articles were "risk factor", "low back pain", "medical person", "health workers", "cross sectional".

\section{Population and Sample}

Health Workers with years of service $\geq 5$ Years and length of time in a day $\geq 6$ hours.

\section{Inclusion Criteria}

The inclusion criteria were a full-text article with a cross-sectional study. The topics of the articles were related to lower back pain in health workers (years of service and length of work in a day). The selected articles were in English. The sample of this study was health workers. The data of the study used multivariate with Adjusted Odds Ratio (aOR).

\section{Operational Definition of Variables} Low Back Pain was the pain felt in the lower back area between the lower ribs angle to the sacrum.

Years of service was the length of time a health worker worked at a workplace (such as in a hospital or clinic).

Length of time in a day was a period of time spent by health workers in a day while working.

\section{Data Analysis}

The data were processed using the Review Manager (RevMan 5.4). The data was measured by the effect size and heterogeneity to determine the model for combining study and forming the final meta-analysis results on the Forest plot.

\section{RESULTS}

The process of searching and selecting the articles through 5 databases can be seen in Figure 1. Figure 2 shows an overview of the study areas used in the meta-analysis which were spread across 3 continents, namely Africa, Asia, and Europe. 
Akbar et al./ A Meta-Analysis on the Risk Factors of Low Back Pain

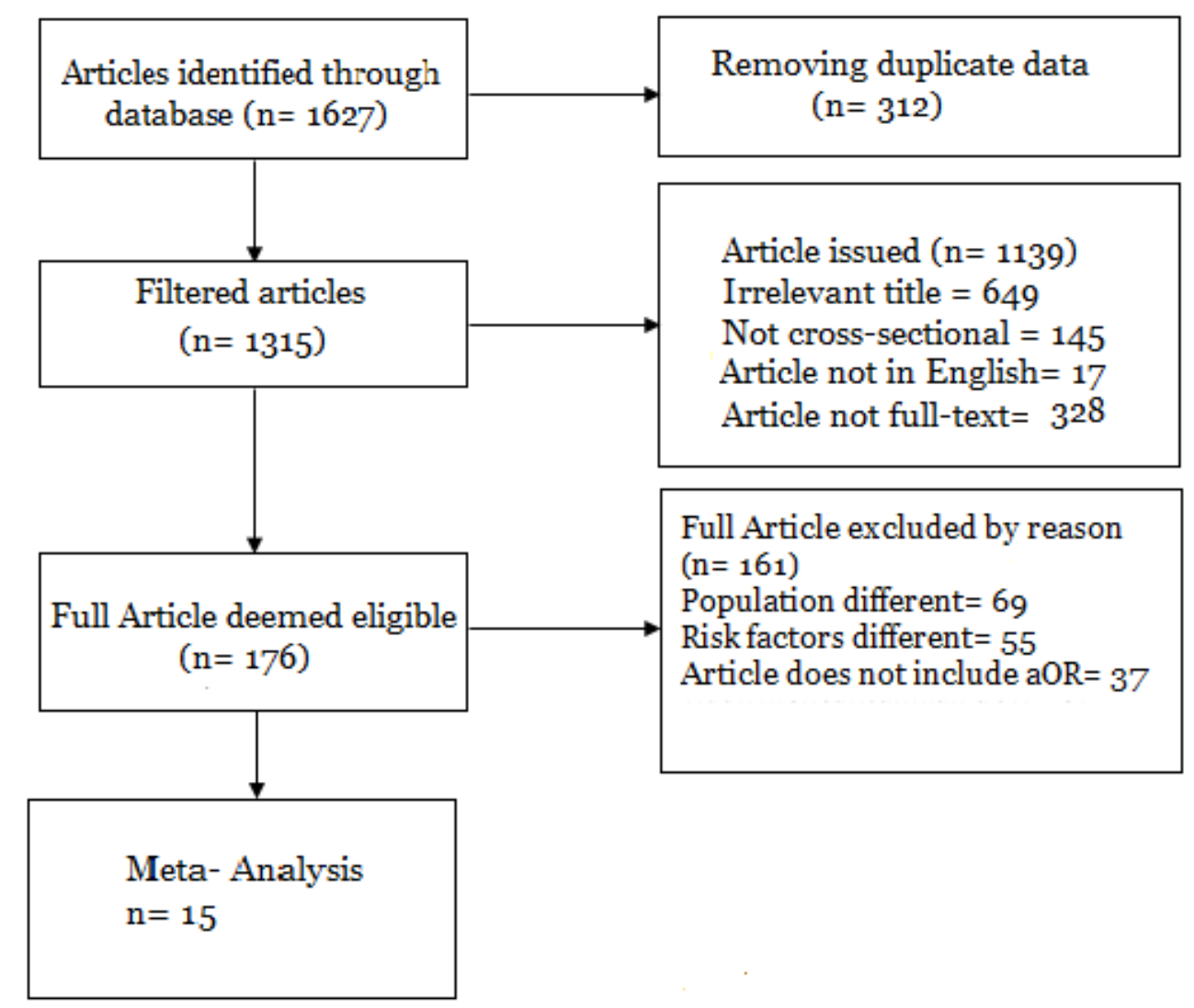

Figure 1. Flowchart of the Review Process

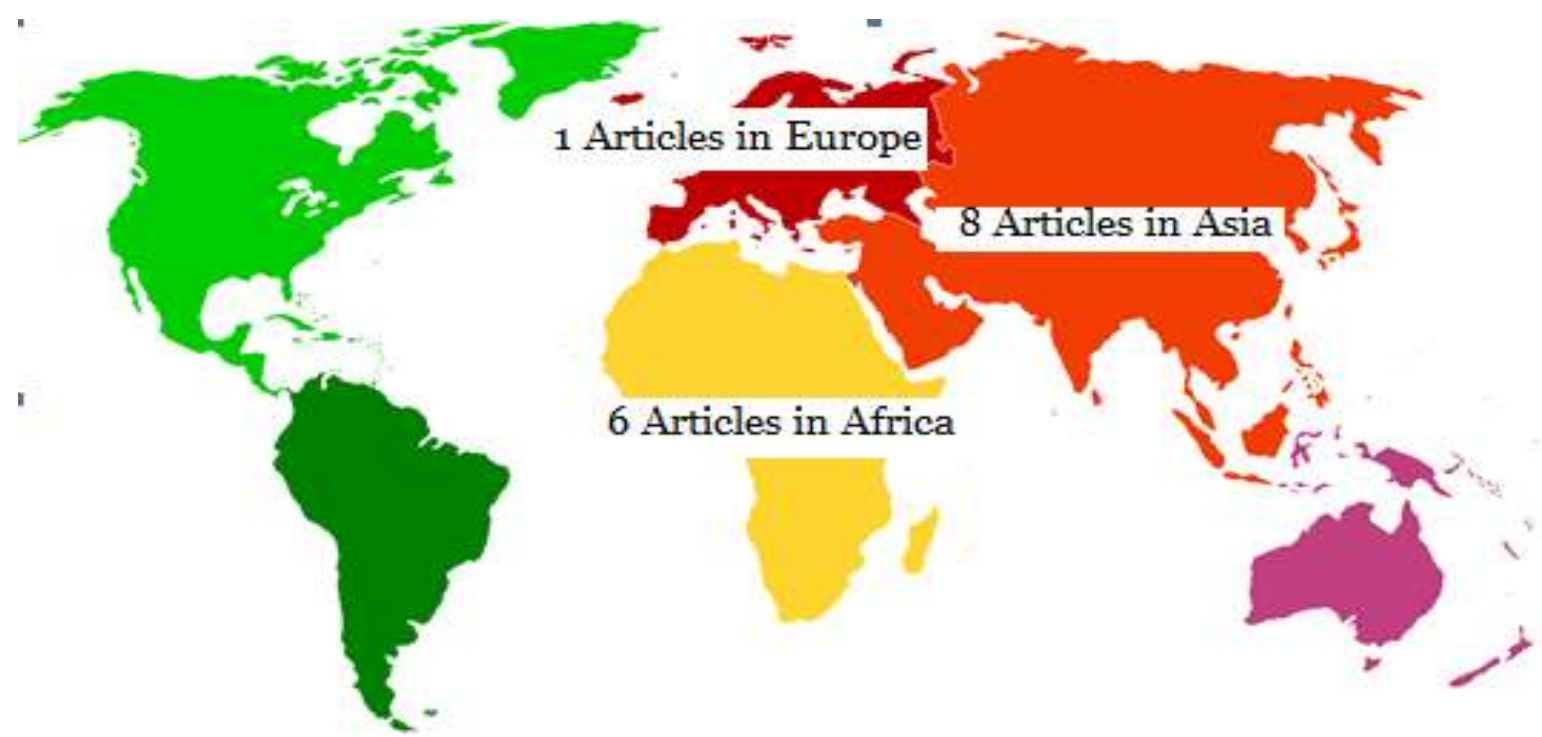

Figure 2. The Overview of the Study Area

\section{Years of service}

There were 10 cross-sectional articles as a reference source for meta-analysis of years of service on the incidence of low back pain in health workers. 
Akbar et al./ A Meta-Analysis on the Risk Factors of Low Back Pain

Table 1. The primary study of sources of meta-analysis on the relationship between years of service and low back pain.

\begin{tabular}{lccc}
\hline \multicolumn{1}{c}{ Author, year } & Country & aOR & CI 95\% \\
\hline Abebe et al, 2015 & Ethiopia & 1.28 & $0.48-3.41$ \\
Belay et al, 2016 & Ethiopia & 1.55 & $0.89-2.70$ \\
Dulon et al, 2007 & Germany & 1.44 & $1.10-1.88$ \\
Ja June et al, 2010 & South Korea & 0.88 & $0.59-1.31$ \\
Bandpei et al, 2011 & Lebanon & 1.22 & $0.83-1.79$ \\
Raesy et al, 2015 & Iran & 2.39 & $1.44-3.97$ \\
Shieh et al, 2016 & Taiwan & 1.36 & $0.49-3.77$ \\
Tanzil et al, 2019 & Pakistan & 2.89 & $1.58-5.29$ \\
Yitayeh et al, 2015 & Egypt & 2.40 & $1.41-4.09$ \\
Youna et al, 2018 & Lebanon & 1.63 & $1.22-2.18$ \\
\hline
\end{tabular}

\section{b. Forest plot}

\begin{tabular}{|c|c|c|c|c|c|c|c|}
\hline Study or Subgroup & log[Odds Ratio] & SE & Weight & $\begin{array}{c}\text { Uads каtıо } \\
\text { IV, Random, } 95 \% \mathrm{Cl}\end{array}$ & \multicolumn{3}{|c|}{$\begin{array}{c}\text { Uads катіо } \\
\text { IV, Random, } 95 \% \mathrm{Cl}\end{array}$} \\
\hline Abebe 2015 & 0.2469 & 0.5004 & $4.0 \%$ & $1.28[0.48,3.41]$ & & & \\
\hline Belay 2016 & 0.4383 & 0.2831 & $8.9 \%$ & $1.55[0.89,2.70]$ & & & \\
\hline dulon 2007 & 0.3646 & 0.1374 & $15.9 \%$ & $1.44[1.10,1.88]$ & & $\mp$ & \\
\hline Ja june 2010 & -0.1278 & 0.204 & $12.3 \%$ & $0.88[0.59,1.31]$ & & & \\
\hline Mohseni-bandpei 2011 & 0.1989 & 0.1965 & $12.7 \%$ & $1.22[0.83,1.79]$ & & & \\
\hline Raesy 2015 & 0.8713 & 0.2585 & $9.8 \%$ & $2.39[1.44,3.97]$ & & & \\
\hline Shieh 2016 & 0.3075 & 0.5208 & $3.7 \%$ & $1.36[0.49,3.77]$ & & & \\
\hline Tanzil 2019 & 1.0613 & 0.3081 & $8.0 \%$ & $2.89[1.58,5.29]$ & & & \\
\hline Yitayeh 2015 & 0.8755 & 0.2714 & $9.3 \%$ & $2.40[1.41,4.09]$ & & . & \\
\hline Youna 2018 & 0.4886 & 0.1478 & $15.3 \%$ & $1.63[1.22,2.18]$ & & - & \\
\hline Total $(95 \% \mathrm{Cl})$ & & & $100.0 \%$ & $1.58[1.27,1.96]$ & & & \\
\hline \multicolumn{5}{|c|}{$\begin{array}{l}\text { Heterogeneity: } \mathrm{Tau}^{2}=0.06 ; \mathrm{Chi}^{2}=19.22, \mathrm{df}=9(\mathrm{P}=0.02) ; \mathrm{I}^{2}=53 \% \\
\text { Test for overall effect: } \mathrm{Z}=4.10(\mathrm{P}<0.0001)\end{array}$} & 0.01 & $>=5$ tahun & 100 \\
\hline
\end{tabular}

Figure 3. The forest plot of years of service on low back pain

The overview of the forest plot shows that the health workers who had 5 years of service increased the incidence of low back pain by 1.58 times compared to the health workers who had $<5$ years of service. The significant

\section{c. Funnel plot}

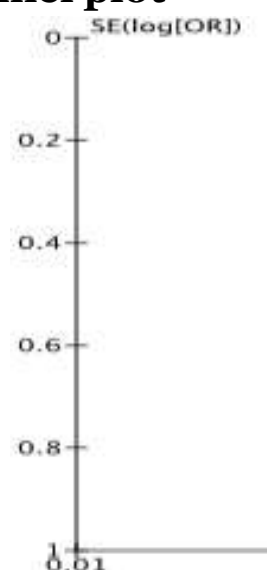

Figure 4. The funnel plot of years of service on low back pain value was $\mathrm{p}<0.01$ and the heterogeneity value of the data was $\mathrm{I}^{2}=53 \%$. Therefore, the distribution of the data was heterogeneous (random effect model). 
Figure 4 shows that there was a publication bias that occurred characterized by asymmetry of the right and left plots. There were 3 study plots on the right plot and 5 plots on the left. Publication bias could also be seen from the imbalance distance among studies. The graph on the right plot was vulnerable between 0.4 and 0 while the graph on the left was vulnerable between 0.6 and 0 .

\section{Length of work in a day}

There were 7 cross-sectional articles as a reference source for meta-analysis of the length of work in a day on the incidence of low back pain in health workers.

Table 2. The primary study of the source of meta-analysis of the relationship between the length of work in a day and low back pain

\begin{tabular}{lccc}
\hline \multicolumn{1}{c}{ Author, year } & Country & aOR & 95\% CI \\
\hline Abebe et al, 2015 & Ethiopia & 3.34 & $1.38-8.08$ \\
Attar et al, 2014 & Saudi Arabia & 3.66 & $1.24-10.80$ \\
Elsherbenyet al, 2018 & Mesir & 2.59 & $1.31-5.12$ \\
Ibrahim et al, 2019 & Malaysia & 1.48 & $1.06-2.07$ \\
Mekkonen, 2017 & Ethiopia & 0.21 & $0.13-0.34$ \\
Mekkonen et al, 2018 & Etiopia & 1.17 & $0.63-2.17$ \\
Tanzilet al, 2019 & Pakistan & 2.30 & $1.28-4.13$ \\
\hline
\end{tabular}

\section{b. Forest plot}

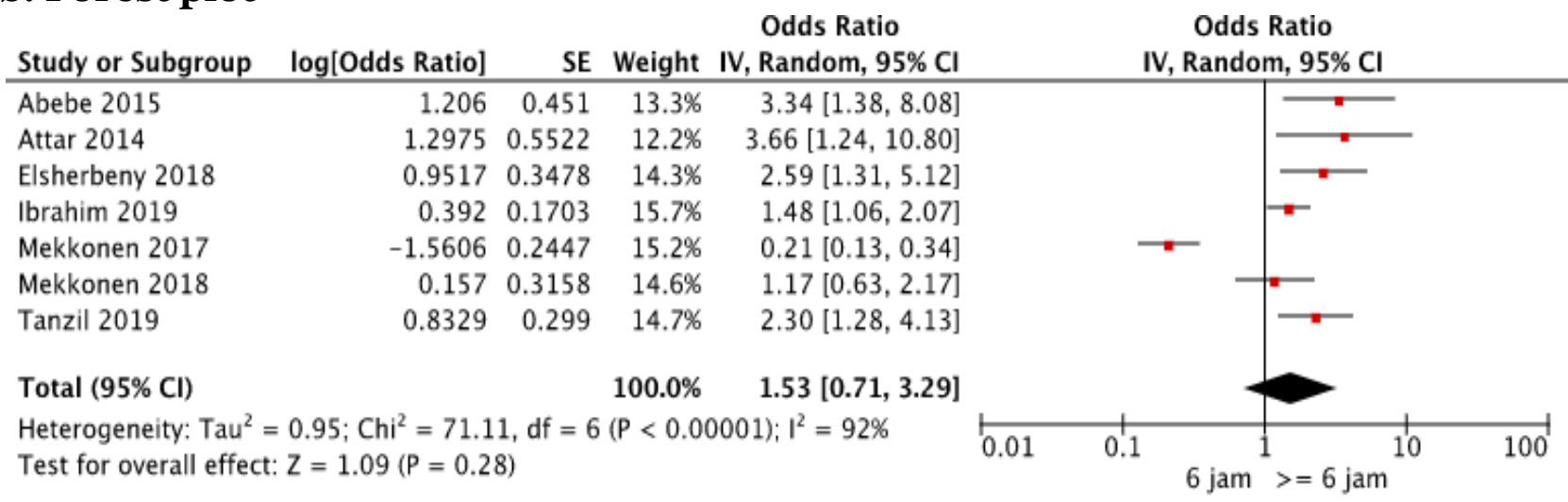

Figure 5. The forest plot of years of service on low back pain

\section{c. Funnel plot}

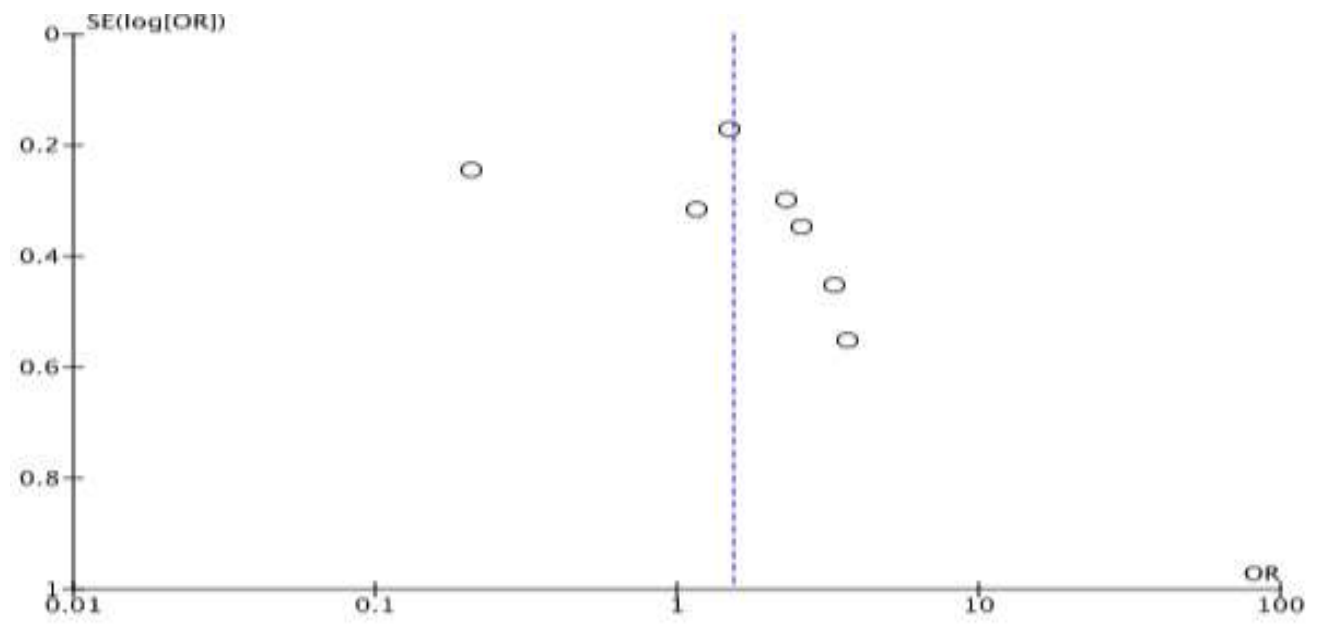

Figure 6. The funnel plot of length of work in a day on low back pain 
The result of the meta-analysis that has been carried out can be seen in Figure 4.6. It shows an overview of the forest plot that the health workers who worked $\geq 6$ hours in a day increased the incidence of low back pain by 1.53 times compared to the health workers who worked $<6$ hours in a day. The significance value was $\mathrm{p}=\mathbf{0 . 2 8}$. It was non-significant and the heterogeneity value of the data was $\mathrm{I}^{2}=92 \%$. Therefore, the distribution of the data was heterogeneous (random effect model).

Figure 6 shows that there was a publication bias that was indicated by asymmetry of the right and left plots. There were 4 study plots on the right plot shows while there were 2 plots on the left. Publication bias could also be seen from the imbalance distance among studies. The graph on the right plot was vulnerable between 0.6 and 0.2 while the graph on the left was vulnerable between 0.4 and o.2.

\section{DISCUSSION}

\section{Length of work on low back pain}

Based on the results of a meta-analysis conducted from 10 articles related to low back pain factors, there was a significant effect between years of service and the risk of low back pain among health workers. Health workers who had $\geq 5$ years of service increased the incidence of low back pain by 1.58 times compared to the health workers who had $<5$ years of service.

The longer the years of service of a worker, the higher the risk of the occurrence of diseases due to work. Repetitive work activities could burden the same muscles and soft tissues over a long period of time ( $\mathrm{Su}-$ santi, 2015). In this meta-analysis study, the risk factor for years of service was the duration of a health worker who worked at a workplace (such as in a hospital or clinic) from the first time working by dividing into 2 groups: $<5$ years of service and $\geq 5$ years of service.

\section{Tenure of work on low back pain}

Based on the result of a meta-analysis carried out from 7 articles related to the low back pain factors, the health workers who worked 6 hours a day increased the incidence of low back pain by 1.53 times compared to the health workers who worked $<6$ hours a day.

Low back pain in health workers due to the risk factors of length of work experienced by these workers occurred because there were a skeletal system and muscle systems in the human body that were interconnected with one another. Therefore, it caused muscle spasms which could cause pain in sufferers. Prolonged muscle spasms could cause vasoconstriction of blood vessels, thus causing ischemia (Pramita et al., 2015).

\section{AUTHOR CONTRIBUTION}

Muh. Syaiful, Dono Indarto, and Setyo Sri Rahardjo collected the data, did data analysis, interpreted the data analysis, and wrote the manuscript.

\section{CONFLICT OF INTEREST}

The authors declare there is no conflict of interest.

\section{FUNDING AND SPONSORSHIP}

This study used personal funds.

\section{ACKNOWLEDGEMENT}

We would like to thank the electronic database provider of PubMed, Science Direct, Scopus, Google Scholar, and Springer Link.

\section{REFERENCE}

Abebe A, Gebrehiwot E, Lema S, Abebe W (2015). Prevalence of low back pain and associated risk factors among Adama Hospital Medical College Staff, Ethiopia. Eur J Prev Med. 3(6): 188-192. https://doi.org/10.11648/j.ejpm.20150306.15

Attar M (2014). Frequency and Risk Factors 
of Musculoskeletal Pain in Nurses at a Cross Sectional Study. BMC Res Notes. 7: 61. doi:10.1186/1756-0500-7-61.

Belay M, Worku A, Gebrie S, Wamisho B (2016). Epidemiology of low back painamong nurses working in public hospitals of Addis Ababa, Ethiopia. East Cent Afr J surg Ethiopia. 21(1): 113-131. https://www.ajol.info/index.php/ecajs/article/view/139040.

Chaman R, Aliyari R, Sadeghian F, Vatani Shoaa J, Masoudi M, Zahedi S, Bakhshi $M$ (2015). Psychosocial factors and musculoskeletal pain among rural hand-woven carpet weavers in Iran. Saf Health Work, 6(2): 120-127. https://doi.org/10.1016/j.shaw.2015.01.001.

Direktur Jenderal Pelayanan Kesehatan. (2018). Low back pain. Kementerian Kesehatan Republik Indonesia. Jakarta

Dulon M, Kromark K, Skudlik C, Nienhaus A (2008). Prevalence of skin and back diseases in geriatric care nurses. International Arch Occup Environ Health. https://doi.org/ 10.1007/s00420-0070292-y.

Elsherbeny E, Elhadidy S, Bahnasawy (2018). Prevalence and associated factors of musculoskeletal complaints among nurses of Mansoura University Children Hospital. Egypt of Occup Med. 42(2):151-166. DOI: 10.21608/ejom.2018.6800.

Farnam F, Raisi F, Janghorbani M, Merghati-Khoei E (2016). How do Iranian women with sexual problems conceptualize sexuality? A qualitative research. Nurs Pract Today. 3(3): 107-115. https://www.tums.ac.ir/1397/o8/o1/N ursing\%2opractice\%2otoday.pdf-f-farnam-2018-10-23-05-43.pdf.

Ibrahim M, Zubair I, Yaacob N, Ahmad M, Shafei M (2019). Low back pain and its associated factors among nurses in public hospital of Penang Malaysia. Int
J Environ Res Public Health. https://doi.org/10.3390/ijerph16214254.

June K, Cho S (2010). Low back pain and work-related factors among nurses in intensive care units. J Clin Nurs. doi: 10.1111/j.1365-2702.2010.03210.x.

Mekonnen T (2019). Work-related factors associated with low back pain among nurse professionals in East and West Wollega Zones, Western Ethiopia. Department of Environmental and Occupational. Pain Ther. doi: 10.1007/s40122-019-0129-X.

Mekonnen T, Yenealem G (2018). Factors afecting health care utilization for low back pain among nurses in Gondartown, northwest Ethiopia. Bmc Res Notes. doi: 10.1186/s13104-019-4231-2. Mohseni M, Shirvani M, Golbabei N, Behtash H, Shahinfar Z, Femandez C (2011). Prevalence and risk factors associated with low back pain in Iranian Surgeons. J Manipulative Physiol Ther. doi: 10.1016/j.jmpt.2011.05.010.

Patrianingrum M, Oktaliansyah E, Surahman E. (2015). Prevalensi dan faktor risiko nyeri punggung bawah di lingkungan kerja anestesiologi rumah sakit Dr. Hasan Sadikin Bandung. Jurnal Anestesi Perioperatif. doi: 10.1585/jap. v3n1.379.

Raesi S, Namvar M, Golabadi M, Attarchi M. (2014). Combined effects of physical demands and shift working on low back disorders among nursing personnel. Int J Occup Saf Ergon. doi: 10.1080/10803548.2014.11077034

Shieh S, Sung F, Su C, Tsai Y, Hsieh V (2016). Increased low back pain risk in nurses with high workload for patient care: A questionnaire survey. Taiwan J Obstet Gynecol. Retrieved from http://www.biomedcentral.com/1756-0500/7/61.

Tanzil S, Tanzil J, Inam B, Abbas A. (2019). 
Akbar et al./ A Meta-Analysis on the Risk Factors of Low Back Pain

Frequency and severity of low back pain among healthcare providers and associated in a tertiary care, public hospital in Karachi. Occup Med Health Aff. doi: 10.4172/2329-6879.1000285. Yitayeh A, Mekkonen S, Fasika S, Gizachew M. (2015). Annual prevalence of self-reported work related musculoskeletal disorders and associated factors among nurses working at Gondar Town Governmental Health Institutions, North- west Ethiopia. Emerg Med. http:/doi.org/10.4172/2165-7548.1000227

Younan L, Clinton M, Fares S, Jardali F, Samaha H.(2018). The relationship between work-related musculoskeletal disorders, chronic occupational fatigue, and work organization: A multi-hospital cross-sectional study. Leading Global Nursing Research. doi: 10.1111/jan.13952. 